OPEN ACCESS

Vol. 7, No. 1, April, 2019

Page. $1-43$

DOI: https://doi.org/10.21107/jaffa.v7i1.6144
JOURNAL OF AUDITING, FINANCE, AND FORENSIC ACCOUNTING (JAFFA)

E-ISSN: 2461-0607 ISSN: 2339-2886

https://journal.trunojoyo.ac.id/jaffa/index

\title{
DEMOGRAPHIC PORTRAIT OF CORRUPTORS IN INDONESIA
}

Khy'sh Nusri Leapatra Chamalinda, Tarjo, Bambang Haryadi

Accounting Department, Faculty of Economics and Business, University of Trunojoyo Madura

Article Info:

Received: 16 Agustus 2019

in revised form: 17 September 2019

Accepted: 08 Oktober 2019

Available Online: 19 December 2019

\section{Keywords:}

Demographic, Corruptors,

Decree of Supreme Court

Corresponding Author:

Email: khyshnusri92@gmail.com
Abstract; Corruption not only cause financial losses to the state but also violates the social and economic rights of society at large. Corruption always draws more attention than other criminal acts (Hartanti, 2005). This research aims to present a demographic portrait of corruptors in Indonesia based on the Decree of Supreme Court of 2015. This research used qualitative method with descriptive analytical approach. There were 92 cases of corruption in the Decree of Supreme Court of 2015 and the number of corruptors analyzed was 106. Informants in this research were psychologists and religious experts. Data collection method for the primary data was interview and the secondary data collection method was investigating decree of Supreme Court documents. The results showed that the majority of corruptors in Indonesia were male (87\%), Muslim (74\%), aged between 46 - 55 years old (51\%), undergraduates (34\%), working as civil servants (45\%), serving as government officials or employees (56\%), and working within the scope of government agencies (57\%).

Abstrak; Korupsi tidak hanya menyebabkan kerugian keuangan bagi negara tetapi juga melanggar hak-hak sosial dan ekonomi masyarakat pada umumnya. Korupsi selalu menarik perhatian lebih dari tindakan kriminal lainnya (Hartanti, 2005). Penelitian ini bertujuan untuk menyajikan potret demografis koruptor di Indonesia berdasarkan Surat Keputusan Mahkamah Agung tahun 2015. Penelitian ini menggunakan metode kualitatif dengan pendekatan deskriptif analitis. Ada 92 kasus korupsi dalam Surat Keputusan Mahkamah Agung tahun 2015 dan jumlah koruptor yang dianalisis adalah 106. Informan dalam penelitian ini adalah psikolog dan pakar agama. Metode pengumpulan data untuk data primer adalah wawancara dan metode pengumpulan data sekunder dengan menyelidiki dokumen Putusan Mahkamah Agung. Hasil penelitian menunjukkan bahwa mayoritas koruptor di Indonesia adalah laki-laki (87\%), Muslim (74\%), berusia antara 4655 tahun $(51 \%)$, sarjana (34\%), bekerja sebagai pegawai negeri $(45 \%)$, melayani sebagai pejabat pemerintah atau karyawan $(56 \%)$ dan bekerja dalam lingkup lembaga pemerintah (57\%). 


\section{INTRODUCTION}

Law functions to provide a sense of justice for every citizen, especially in Indonesia to create harmony among citizens. The law was made to realize social justice for all Indonesian people in accordance with the 1945 Constitution. However, the reality of the national goals has not yet fully achieved. One of them is due to the rampant corruption cases. Corruption is a familiar term to Indonesian people. These corrupt actions are going rampant and are carried out by various unlawful groups. Corruption always draws more attention than other criminal acts (Hartanti, 2005).

In dealing with corruption, it is better not only to judge in terms of the amount (material) that has been corrupted, but rather to the act of corruption which clearly violates the people's rights and tarnishes the image of Indonesia as a nation. Corruption cannot be eliminated at once; it requires a process. Corruption eradication can be performed in various ways, one of them is through the mass media. Putra (2017) in his research stated that the way mass media preserving the grand narrative of corruption eradication is through creating a common enemy for corruptors. With a strong determination from the government and law enforcement officials to provide strict sanctions (giving a deterrent effect) to the corruptors, it does not rule out the possibility of corruption in Indonesia to be minimized.

In Indonesia, corruption is regulated in Law No. 31 of 1999 and Law No. 20 of 2001 on Eradication of Corruption (PTPK), but the corruption still occurs. The emergence of corruption can be caused by several factors (Syamsuddin, 2011), such as the poor education (religion, morals, and ethics), no severe sanctions against corruptors, the absence of transparent government system (good governance), economic factors (low officials' salaries), poor management and lack of effective and efficient supervision, and modernization which causes a shift in the values of life that develops in society.

Here are results of a survey conducted by several institutions related to the demographics of corruptors / fraudsters, including Association of Certified Fraud Examiners (ACFE, 2014) regarding the profile of a fraudster including demographic information of more than 1,400 work fraudsters in more than 100 countries. The survey results show that the perpetrator was dominated by male than women with a ratio of 2 : 1 , men $(67 \%)$ and women (33\%). Regarding the age, it is known that $52 \%$ of perpetrators were between 31 - 45 years old, but old age perpetrators tend to cause greater losses.

The survey conducted by KPMG used data from 348 fraud cases from 69 countries (KPMG, 2011). The survey results show that the average profile of fraudsters was male $(87 \%)$, aged between $36-45$ years old $(41 \%)$, working in the finance department or related fields $(32 \%)$, holding senior management positions $(53 \%)$, has worked in a company for more than 10 years (33\%), in collaboration with others to commit crimes, the motivation to commit fraud is greed and work pressures.

Indonesia Corruption Watch (ICW) conducted a survey with the data taken for cases that was successfully monitored from January 1 to December 27, 2014 with a total of 629 cases. One of the survey results is that corruption based on the highest position was performed by officials or employees of the Local Government/Ministry. Corruption based on the highest institution mostly occurs in the Local Government (ICW, 2014).

The research of Kapardis \& Kapardis (2004) shows that the majority of fraudsters were male, aged 35-45 years old, married, have higher educational background, and applied to those who had financial problems and avaricious, do not have a criminal record, holding positions in financial, rationalizing their fraud behavior, specializes in thievery, acting alone, using fake documents, sacrificing two or more people they know and convicted of several charges.

The research of Rahmana (2013) shows that the majority of corruptors in East Java committed corruption of between IDR 100 million - IDR 1 billion (47\%), aged between 40-50 years old $(44 \%)$, male (87\%), come from high-level attorney areas $(41 \%)$, work as civil servants (55\%), and having Associated/Bachelor degree (43\%). This research explored the demographic of corruptors in Indonesia based on corruption cases in the Decree of Supreme Court of 2015. It is expected that this demographic of corruptors to be beneficial for various parties in eradicating corruption in Indonesia. 


\section{LITERATURE REVIEW AND HYPOTHESES DEVELOPMENT}

Cressey in (Singleton \& Singleton, 2010) summarized the factors causing people to commit fraud. The results of Cressy's research are called the "fraud triangle". Fraud triangle consists of pressure, opportunity, and rationalization. Pressure is an impetus that causes a person to commit fraud, such as a difficult financial situation, and mostly driven by greed, and luxurious lifestyle. Opportunity is usually caused by the existing situations such as poor internal control of an organization, lack of supervision, and so on. The last factor is rationalization in which the perpetrators of fraud seek rational justification to justify their actions. This justification can occur when the perpetrator wants to make his family happy, feeling entitled to get something more (position, salary, promotion) because he has served the company for a long time, and so on.

Gone theory by Jack Bologna (Zaini, 2015) also stated that there are four root causes of fraud called GONE, consisting of greed, opportunity, need, and exposure. Greed related to the greed and greediness of an individual, because it can be said that corruptors are people who are not satisfied with their achievements. Opportunity is associated with the system providing opportunities for corruption, such as poor monitoring system, irregular control system, and so on. Sometimes the higher the position of someone, the greater the chance of him committing fraud. Need is associated with mental attitude that is never satisfied, full of consumerism, and infinite needs. Exposure is associated with the disclosure of minor penalties to perpetrators of fraud or penalties that do not deter the perpetrator. This does not rule out the possibility of fraud to be repeated if the penalties or sanctions are minor.

Indonesia also has Indonesia Fraud Survey (SFI) established by the ACFE Indonesia Chapter in collaboration with the White-Collar Crime Research and Prevention Centre of STIE Perbanas Surabaya. One of the results of SFI research (2016) in terms of fraudsters is that the majority of fraudsters hold positions as managers $(40.3 \%)$, the frequent amount loss due to fraud based on positions is IDR 100 million to IDR 500 million, it can be detected in general within a period of 0-12 months, the majority of the average age of fraudsters are 36-45 years old (47\%), and dominant fraudsters are male $(92 \%)$. This is also in line with Kennedy and Siregar's research (2017) which also refers to the results of the Indonesian Fraud Survey.

In addition, in the past years, ACFE (2018) also presented a survey on the profile of fraud. Data analyzed were 2,690 fraud cases reported by 125 countries. This survey focused more on how fraud impacts the Asia Pacific region based on 220 cases. The survey results show that the fraud are: a) Misuse of assets $(80 \%)$ causing the lowest average loss of USD 180,$000 ; 2)$ the lowest level of fraud is financial statement fraud $(13 \%)$ which causes the highest average loss of USD 700,000 ; 3 ) Corruption $(51 \%)$ and causes an average loss of USD 500,000.

\section{RESEARCH METHODOLOGY}

This research used qualitative method with descriptive-analytical approach to obtain an objective explanation of the demographic of perpetrators in the Corruption Case based on the Decree of Supreme Court of 2015. The data and information collected were processed and analyzed to obtain a portrait of corruption in Indonesia. This was performed by describing the facts followed by the analysis.

Demographic of the corruptors in this research were sex, religion, age, education, occupation, position and institution. Corruption data was obtained from the Decree of Supreme Court directory website. The data processed were 92 cases of corruption in the Decree of Supreme Court of 2015 with a total of 106 corruptors. In addition, there were 2 informants who were psychologist and religious expert to obtain a deeper explanation and understanding. 


\section{FINDINGS AND DISCUSSION}

\section{Corruptors Related to Gender: Majority Male}

In terms of sex, from 106 corruptors in Indonesia, it can be seen that the perpetrators were male (87\%). This result is in line with the results of a survey conducted by several institutions such as (ACFE, 2014) and (KPMG, 2011). This result is also in line with Rahman (2013) and Kapardis \& Kapardis, (2004), who also proved that the majority of corruptors/ fraudsters were male. Based on the Decree of Supreme Court of 2015, the male corruptors are for instance, M. Akil Mochtar, Andi Alfian Malarangeng, Tubagus Chaeri Wardana Chasan and others.

Why men are more prone to corruption than women? In fact, there is no gender discrimination in law. The following is an explanation of Wati (psychologist) in assessing acts of corruption or other crimes related to one's gender:

\footnotetext{
"Actually, there is no difference between men or women in committing crimes, anyone can commit crimes. Thus, it is not determined by gender. Because, experts never say if the structure of men and women determine someone to behave deviant. The factors of needs, the environment, and opportunities are aspects that affect a person in behaving"
}

Wati's opinion above implies that corruption or other deviant actions can be performed by anyone. In addition, experts have also never stated that gender will determine someone to behave in a deviant and fraudulent manner. However, there are factors that affect someone acting fraud, such as needs, opportunities, and the environment.

We can also find out more about theories that can explain crime behavior (Margaretha, 2013). Sigmund Freud theory in the perspective of psychoanalysis has its own views about what makes someone commit a crime. The imbalance of the relationship between Id, Ego, and Superego make humans weak and consequently, someone is more likely to commit deviant or bad deed. Id is a biological impulse (such as eating, drinking, affection, ignoring what the people say or think because the important thing is to satisfy the desires. Ego (rational component) functions to bridge the demands of the Id with the reality of the outside world. In other words, if the Id only produces desires, then the ego serve to fulfill them. Superego (social component) acts as a personality police, a conscience that seeks to fulfill our ideal desires. According to Freud, bad deed occurs if it is driven by a poor conscience, which is unable to resist the strong urges (such as the desire to own property, wealth, and luxury) even though obtained from unjustified methods. According to this view, bad deed is not the result of a criminal personality, but the weakness of Ego. Ego that is unable to bridge the needs of Superego and the Id will be weak and make it vulnerable to deviations.

The fraud triangle theory put forward by Donald R. Cressey also plays an important role in explaining why someone commits corruption. Pressures are for example pressure from the superior, difficult financial conditions, and luxury lifestyle. The second factor is opportunity, such as using the opportunity for his position to commit corruption. Minor sanctions can also be used as an opportunity for corruption as well as poor internal control within an agency/company. The last factor is rationalization, in which the justification by the corruptors such as want to make their family happy, feeling entitled to get something more from the company, and so on.

Although this research based on the Decree of Supreme Court of 2015, it is stated that men are the majority and more prone to corruption, yet it cannot rule out the possibility that one day women will rank first in terms of corruption. It can be concluded that anyone, both men and women can commit corruption.

\section{Corruptors from Religious Aspect}

The perpetrators of corruption are frequently linked to the religion or belief. This problem does not lie in the religion teaching embraced by the corruptors, but rather the factors causing someone to violate their religion teaching by committing corruption. Indonesia has various religions and beliefs. There are 6 officially religions in Indonesia which are Islam, Protestant Christianity, Catholicism, Hinduism, Buddhism, and 
Confucianism. According to the census results in (BPS, 2010), it obtained the data of (87.18\%) Muslim, Christian (6.96\%), Catholic (2.9\%), Hindu (1.69\%), Buddhist $(0.72 \%)$, Confucius $(0.05 \%)$, other $(0.13 \%)$, and $(0.38 \%)$ unstated or not asked. The results of the census show that the majority of Indonesia population is Muslim.

From the 106 corruption perpetrators based on the Decree of Supreme Court of 2015, the highest was committed by Muslims (74\%). Although not all Muslims are the perpetrator, other people would unanimously say that the corruptors are Muslims, because the majority of the population of this country are Muslims and this is a risk of the majority population. Corruption is prohibited in the teachings of any religion including Islam.

In Islam, corruption is strictly forbidden and invokes wrath of Allah SWT because it is a grave sin and destruct Haqooq ul Ibaad (the duty we owe to mankind), and has a devastating effect on the social and economic development of a nation (Azad, Khan, \& Akter, 2013). Corruption can also cause destruction to public good and is contrary to the purpose of the sharia. Islam forbids and prohibits acts of corruption and can be rewarded with severe sanctions (Bahri, 2015). The Qur'an teaches that every act and action violating justice is treated as corruption, so that all behaviors destructing values and distort the Islamic moral framework are called "fasaad" which is an Arabic word that can be translated as corruption. The concept of corruption in the Qur'an is broader than the main concept of corruption which is an abuse of power. Therefore, the term "fasaad" includes all human behavior that interferes with individual life and social harmony, damages the environment, and ultimately weakens the sustainable development.

The Qur'anic verses and hadith do not explicitly mention about the types of corruption, but several terms mentioned by Qur'an and hadith give hints and indicate the types of corruption globally. For instance, the prohibition on taking other's property wrongfully and bribery, which is closely related to corruption. Bribery has been going on for quite a long time in this country. The Prophet Muhammad criticized this bad tradition that contemporaries did at that time (Saefulloh, 2013). According to a research (Saefulloh, 2013), there are 5 types of Jarimah (Islamic Law) that are close to the type of corruption, namely ghulul (embezzlement), risywah (bribery), khianat (betrayal), shariqah (theft), and hirabah (robbery).

In addition, the research (Shadabi, 2013) shows that Islam and Christianity have no significant effects on corruption. In essence, the results of this study indicate that religion does not increase corruption. In other words, religion is an internal barrier to avoiding bad actions but religious orders are not enough to avoid corruption. This research also shows that corruption and its control are not the output of every religion, when religion does not create social norms. Maybe we should focus on other cultural factors such as the media in enhancing anti-corruption programs.

Why Islam clearly prohibits corruption, but the Decree of Supreme Court of 2015 stated that the highest corruption was committed by Muslims. According to Makruf, one of the ustadz in $\mathrm{X}$ area argued about this:

"Today, most Muslim only claim to be Muslim. They are practicing the pillars of Islam (pray, fasting, pilgrimage) but still committing corruption. It violates the prohibition of Islam and does not fully implement the teachings of Islam. Prayer, for example, can prevent bad deeds according to Qur'an. However, if people are praying diligently but still committing corruption, it means that the prayer is only limited to fulfill the obligations. They do not implement the wisdom of prayer in everyday life. Islam also teaches peace, beauty, and safety. Those who commit corruption have actually destructed the peace and safety of themselves and others. The highest corruption rate in Indonesia may be committed by Muslim, yet it is possible since the majority people holding the highest positions such as officials, are mostly Muslim."

As Muslims, it is an obligation to obey all orders of Allah and avoid His prohibitions. A Muslim committing corruption means he has violated the prohibitions of Islamic teachings. In other words, the person only claims to be Muslim but his actions do not 
reflect the teachings of Islam. Islam also teaches peace, beauty, and safety. Those who commit corruption have actually destruct the peace and safety for themselves and others. This is confirmed by the explanation of Wati, a psychologist in assessing corruption related to religion:

"In principle, religion teaches no bad deed. Every religion teaches goodness. Thus, one's actions are not held accountable for their religion, but internalization of their religious values that they do not fully understand. The first thing is understanding and the second is internalizing religious values. So, when making a decision to commit a bad deed, no religious considerations are presented. So, it is not the religion that is bad, but the understanding and internalization within him, in which the religious values are not internalized"

The researcher also believes that in principle there is no religion that teaches bad deeds, but goodness, including Islam. Someone who decides to commit bad deeds, in this case, is not due to the religion, but the understanding and internalization of his religious values which are not fully understood as well as no religion values present there. After understanding the above explanations, hopefully we can further enhance our faith and self-awareness of the adverse effects of corruption to avoid corruption. However, the prevention and eradication of corruption is the responsibility of all humans.

\section{Corruptors Related to Age: Middle Age are Vulnerable to Corruption}

From the 106 corruptors, the highest perpetrators aged between 46 - 55 years old $(51 \%)$ or middle adulthood. This is in line with the research (Rahmana, 2013) which stated that the majority of corruptors in East Java $44 \%$ is 40 - 50 years old. In this case, the researcher said that $46-55$ years old (middle adulthood) is a mature age, in which a person already has enough experience in his work. Someone also tends to hold important positions when he reached 40 years old and older. At that age, someone already knows the ins and outs or perks in his work, so it is often used as an opportunity to commit corruption in order to achieve personal goals and gain profits.

One example of the corruptors based on the Decree of Supreme Court of 2015 between 46 - 55 years old and related to the bribery of a judge (M. Akil Mochtar) is 52 years old. Wati, a psychologist, gave an opinion on why people between 46 - 55 years old are vulnerable to corruption or other criminal acts:

"The age range of 46 - 55 years old is classified as middle adulthood. Theoretically, middle age in the task of development is mature and should be economically stable. For those who are economically unstable, then what will they do? They will look for alternative ways in order to be stable in financial. Looking for shortcuts. Why? Because it is not supported by religious values".

From this opinion and the previous explanation, the age range between 46 - 55 years old theoretically includes in middle adulthood. One of the tasks of development in middle age is to maintain economic stability. If someone at that age is not yet economically stable, then he will try to find alternative ways or shortcuts in order to be stable instantly. If the need factor (poor financial condition), the opportunity and influences from the surroundings support the corruption, it will be committed. However, if the understanding and internalization of one's religious values is strong, then any factor that supports corruption will have no effect.

In addition, another opinion stated that currently corruption perpetrators in Indonesia are mostly performed at young age (regeneration of corruption). Abraham Samad said that currently, there are many young leaders who commit corruption, who are under 35 years old on average. He added that the perpetrators of corruption seemed to regenerate at younger age, for example Muhammad Nazaruddin corrupted at the age of 35 years old, Angelina Sondakh committed corruption at 33 (Fajerial, 2014).

Anyone can commit corruption. Both young and old may be fallen into the dark circle of corruption. Despite their age, the older generation and young generation have the same goal, which is to make the state money for their personal or group interests. 
Even today, acts of corruption are rarely committed individually but collectively. Regeneration of corruption will continue to be invisible, yet can be perceived.

\section{Corruptors Related to Educational Background: One's Moral Quality Is Not Always in Line with Academic Degree}

According to John in (Maulia, 2014), education is a process of experience. A quality person is inseparable from the factor of education. By acquiring an education, one can gain knowledge and insight as well as become skilled and expert in certain fields. From the 106 perpetrators based on the Decree of Supreme Court of 2015, the majority of perpetrators are undergraduates (34\%). This is in line with the research (Rahmana, 2013) stating that the majority of corruptors in East Java are Associate/Bachelor degree graduates $(43 \%)$ and another research (Kapardis \& Kapardis, 2004) also showing that the majority of fraudsters have higher educational status.

One of the research results (Wilopo, 2006) stating that the higher the level of individuals' moral reasoning, the less they commit accounting fraud. Furthermore, according to ACFE 2014, fraudsters with bachelor's degree cause losses two times higher on average. Well-educated fraudsters also have more technical knowledge and greater expertise, thus facilitating them to succeed in conducting fraud schemes.

It raises a question for us, why people who have higher education background are actually vulnerable to corruption. The researcher believes that the educated people even undergraduates certainly have sufficient knowledge and understand more or less about law in Indonesia. However, why people who understand the law violate it, even when they know the consequences of corruption. This may be lie in the weakness of law in Indonesia or other factors. Looking at the current phenomenon in Indonesia, one's moral quality is apparently not always in line with his academic degree (Rastika, 2013).

In general, corruption is committed by educated people or experts in certain fields. In addition to being well-known or highly educated, they are also experts, cunning, knowing the opportunity for corruption, and smartly avoid the law. The corruption perpetrators based on the Decree of Supreme Court of 2015 who has higher educational background but stumbled on corruption cases are such as Hambalang corruption case (Andi Alfian Mallarangeng), bribery of judge (M. Akil Mochtar), etc. The educated people are frequently entangled in corruption cases.

According to Abraham Samad, the formal education system in Indonesia focuses more on cognitive aspects (based on empirical factual knowledge), so it is unsurprising that Indonesian school students are excellent in the Olympics related to science. Because of prioritizing the cognitive aspects, the essential purpose of education is ruled out, i.e. character building. Abraham assessed that the Indonesian education system has not been able to create students who have strong characters, so that they are vulnerable to corruption (Rzk, 2014).

One serious problem in the education of Indonesia is morality issues. Educating individuals to be smart and skilled is relatively easier compared to educating moral. Therefore, moral education committing to the steps educators should take to teach the young generation about values and virtues that will shape them into good human beings is needed (Zubaidi in (Sumiarti, 2007). The researcher agrees with the research results (Sumiarti, 2007) stating that anti-corruption education is significant as a systematic and massive effort to eradicate corruption. For this reason, education needs to be addressed by prioritizing the educational process aimed at intelligence, skills, and character building. This is the time to fix distortions in education and ignorance of moral values in order to create young generation who against corruption.

The following is the opinion of Wati, a psychologist, in assessing the correlation between education and acts of corruption:

"Is the bachelor degree authentic or not? Theoretically, the higher education of a person, the more mature or more logic he is. Except for the fake bachelor degree (smirking). That's why there are three factors with greater effects (need, opportunity, and influence from the surrounding) and also supported by the absence of religious values, and maybe fake certificates." 
It can be concluded that the higher education of a person, the more mature or logic he is. There are several factors why someone with high education, such as undergraduate, conducts corruption including the absence of consideration of religious values, need factor, influence from the surrounding, opportunity, etc.

\section{Corruptors Related to Occupation: Bureaucrats Still in the Spotlight}

Corruption in the workplace can be inflicted from habits or pleasures of taking the others' rights by committing deviation or fraud. For individuals with corrupt mentality, corruption seems to be a hobby, so that no matter how good a governance and system is built, they will be smarter to commit corruption. From the 106 perpetrators of corruption based on the Decree of Supreme Court of 2015, the highest number of perpetrators worked as civil servants $(45 \%)$. This is in line with the research results (Rahmana, 2013) stating that the majority of corruptors in East Java worked as civil servants $(55 \%)$.

One example of corruptors who worked as civil servant based on the Decree of Supreme Court of 2015 is a civil servant who also serves as the committee for goods/services procurement in the case of mango seedlings procurement in the Agriculture Office of X District. The perpetrators had made their owner estimate (OE) determining the unit price of mango seedlings but it was unreasonable/much more expensive than the market price and it was not determined from the survey, but only from the estimation of the procurement committee. This caused the price of mango seedlings procurement to be higher, thus harming the state financial.

It is a shame that the bureaucrats who should be able to protect, serve, and present a good image to the community, committing corruption. This is a question for us why perpetrators of corruption, especially those who work as civil servants are vulnerable to corruption, even though not all civil servants in Indonesia are corrupt. The push factors for someone who works as a civil servant in committing corruption are varied. If we look at the corruption phenomenon in the Decree of Supreme Court of 2015, greed, pressures from superiors, civil servant salaries, indecisive sanctions, and poor internal control, give the opportunities to corruption.

The following is an opinion from Wati in assessing the relationship between civil servant and corruption:

"Civil servants have greater opportunities for corruption because the financial statement is made in advance. For private sector, the financial statement is made after the activities. However, the civil servant is ordered to make financial statement first, then the activities are carried out later on. Therefore, every Budget proposal is prepared first, even though the activities have not yet been conducted. The budget in the Budget Proposal is raised, marked up "

It can be concluded that civil servants have greater opportunities or chances in committing corruption. This is illustrated by the corruption case based on the Decree of Supreme Court of 2015, in which most of the corruption cases committed by civil servants are in goods/services procurement projects. Goods and services procurement is one of the holes of budget leak (Faisol, 2014).

\section{Corruptors Related to Institution: The Increase of Corruption Perpetrators within Governmental Scope}

It is undeniable that violations such as corruption frequently occurs in an agency/institution, whether committed individually or in collective. From the 106 corruption perpetrators in Indonesia based on the Decree of Supreme Court of 2015, many acts of corruption occur within the governmental agencies $(57 \%)$. This is in line with the survey results (ICW, 2014), in which the highest corruption in 2014 occurred in local government.

For example, the perpetrator working in a government agency based on the Decree of Supreme Court of 2015 is a civil servant and Secretary of the Committee of Procurement Result Examination at the Public Works Service of X District. He had performed his duty in assessing works in the field. However, based on the instruction of Proxy of Budget User, he made and signed the minutes of acceptance report without 
rechecking the work results of the contractor. In fact, the work had not been $100 \%$ complete and unmatched with the fact in the field or the work results did not meet the work contract. The perpetrators also forged the signature of the Head of Committee of Procurement Result Examination so that the fund disbursement could be carried out.

The number of corruptors within the government agencies is increasing. It makes the public disappointment with the government is also increasing to no surprise. A clean government and corruption eradication are the agenda and hope of the Indonesian. However, it cannot be denied that the failure of this agenda and the fading of the community hopes are due to corruption committed by the government officials themselves. Even in some cases, corruption by government officials or employees are actually supported by some entrepreneurs. By looking at this phenomenon in which corruption occurs in the government circles, it can be said that the opportunity factor of fraud triangle and gone theory greatly affects someone to corrupt. Minor sanctions, poor internal control in an agency can be taken as an advantage to commit corruption.

In the research (Apriadi, 2014) related to fraud in government institutions, it stated that salary, effectiveness of internal control system, and organizational ethical culture variables affect the occurrence of fraud in government agencies. This provides empirical evidence that fraud occurring in government institutions is affected by salary, effectiveness of the internal control system, and the organizational ethical culture.

The increase of corruption perpetrators in several governmental scopes based on the Decree of Supreme Court of 2015 happened in the Education Board, Agriculture Office, Public Works Service, Local Government, Health Institutions, and so on. Furthermore, according to Wati, in assessing the relationship of government agencies and acts of corruption, she stated:

"In private companies, the employees work hard because they receive the salary according to their works. Unlike civil servants, they consider it from the position. Even though they have the same position, they have different jobs, but receive equal salary"

According to Wati, a psychologist, it is reasonable that someone who works at a company (private) receive salary according to the works. However, it is different from someone who works as a civil servant in a government agency. Even though the position is the same, the job is different, while the salary received is equal. In this case, it can be concluded that there are several driving factors of corruption within the scope of government agencies such as salary and poor internal control system. Consequently, opportunities are wide open for corruption.

\section{CONCLUSION AND SUGGESTIONS}

Based on the research related to the demographic of corruptors, from 106 perpetrators based on 92 cases of corruption in the Decree of Supreme Court of 2015, it is concluded that the majority of corruption perpetrators in Indonesia are male $(87 \%)$, Muslim (74\%), aged between 46 - 55 years old (51\%), undergraduates (34\%), worked as civil servants $(45 \%)$, holding position as or government officials or employees $(56 \%)$, and worked within the scope of government agencies (57\%). This research has some limitations, one of them is that the researcher did not interview the corruption perpetrators. For the future research, it is suggested to interview the perpetrators of corruption directly and adding more Decree of Supreme Court to be analyzed, so that it will produce more in-depth information. 


\section{REFERENCES}

ACFE. (2014). Report to The Nations On Occupational Fraud and Abuse. Global Fraud Study.

Apriadi, R. N. (2014). Determinan Terjadinya Fraud Di Institusi Pemerintahan. Universitas Brawijaya Malang.

Azad, M. S., Khan, M., \& Akter, S. (2013). Corruption in Islamic Perspective and the Roles of Information and Communication Technology (ICT) to Control It. Islamic Management and Business, Vol.5 No11.

BPS. (2010). Penduduk Menurut Wilayah dan Agama yang Dianut. Retrieved April 30, 2016, from http://sp2010.bps.go.id/index.php/site/tabel?tid=321\&wid=0

Creswell, J. W. (2014). Pendekatan Kualitatif, Kuantitatif dan Mixed. Edisi Ketiga. Yogyakarta: Pustaka Pelajar.

Faisol, I. A. (2014). Pengaruh Penerapan E-Procurement Terhadap Pencegahan Fraud Di Sektor Publik. Jurnal Jaffa, Vol.02 No2.

Fajerial, E. (2014). KPK: Banyak Koruptor Muda, Ada Regenerasi Korupsi. Retrieved May 25, 2016, from http://m.tempo.co/read/news/2014/11/10/063620979/kpkbanyak-koruptor-muda-ada-regenerasi-korupsi

Hartanti, E. (2005). Tindak Pidana Korupsi. Jakarta: Sinar Grafika.

ICW. (2014). Tren Pemberantasan Korupsi Tahun 2014. Retrieved February 21, 2016, from http://www.antikorupsi.org/id/doc/tren-korupsi-2014

Kapardis, A., \& Kapardis, M. K. (2004). Enhancing Fraud Prevention and Detection by Profiling Fraud Offenders. Criminal Behaviour and Mental Health.

KPMG. (2011). Who Is The Typical Fraudster?. KPMG Analysis Of Global Patterns Of Fraud.

Margaretha. (2013). Mengapa Orang Melakukan Kejahatan? Retrieved March 30, 2016, from http:/ / psikologi.unair.ac.id/artikel-mengapa-orang-melakukan-kejahatan/

Maulia, S. T. (2014). Pengaruh Usia, Pengalaman, Dan Pendidikan Dewan Komisaris Terhadap Kualitas Laporan Keuangan (Studi empiris pada perusahaan real estate dan property yang go public di Bursa Efek Indonesia tahun 2010-2012). Universitas Dipenogoro.

Rahmana, A. F. (2013). Analisis Pola Hubungan Kerugian Negara Akibat Korupsi Dengan Demografi Koruptor di Jawa Timur. Jurnal Sains Dan Seni Pomits, Vol 2 No 2.

Rastika, I. (2013). Orang-orang Pintar Terjerat Korupsi. Retrieved May 10, 2016, from http: / / nasional.kompas.com/read/2013/08/16/0919579/Orangorang.Pintar.Terjerat.Korupsi

Rzk. (2014). Ketua KPK: Korupsi Ternyata Meregenerasi. Retrieved May 26, 2015, from http: / / www.hukumonline.com/berita/baca/1t54879cbe2fccd/ketua-kpk--korupsiternyata-meregenerasi

Saefulloh, M. (2013). Tindak Pidana Korupsi Dalam Perspektif Hukum Islam dan UU No. 31 Tahun 1999 Tentang Pemberantasan Tindak Pidana Korupsi Jo Uu No. 20 Tahun 2001 Tentang Perubahan atas Uu No. 31 Tahun 1999. Universitas Mataram.

Shadabi, L. (2013). The Impact of Religion on Corruption. The Journal of Business Inquiry, Vol. 12, 102-117.

Singleton, T., \& Singleton, A. (2010). Fraud Auditing and Forensic Accounting. USA: Jhon Wiley \& Sons.

Sugiyono. (2009). Metode Penelitian Kuantitatif, Kualitatif dan R \& D. Bandung: Alfabeta.

Sumiarti. (2007). Pendidikan Anti Korupsi. Jurnal Pemikiran Alternatif Pendidikan, Vol12 No2.

Syamsuddin, A. (2011). Tindak Pidana Khusus. Jakarta: Sinar Grafika.

Wilopo. (2006). Analisis Faktor-faktor yang Berpengaruh Terhadap Kecenderungan Kecurangan Akuntansi: Studi pada Perusahaan Publik dan Badan Usaha Milik Negara di Indonesia. Simposium Nasional Akuntansi (SNA) 9 Padang.

Yanto, O. (2007). Pejabat, korupsi, dan penjara. Retrieved June 16, 2016, from http:/ / www.antikorupsi.org/en/content/pejabat-korupsi-dan-penjara

Zaini, M. (2015). Analisis Pengaruh Fraud Diamond dan Gone Theory Terhadap Academic Fraud (Studi Kasus Mahasiswa Akuntansi Se-Madura). Simposium Nasional Akuntansi 18. 
ACFE. (2014). Report to The Nations On Occupational Fraud and Abuse. Global Fraud Study.

Apriadi, R. N. (2014). Determinan Terjadinya Fraud Di Institusi Pemerintahan. Universitas Brawijaya Malang.

Azad, M. S., Khan, M., \& Akter, S. (2013). Corruption in Islamic Perspective and the Roles of Information and Communication Technology (ICT) to Control It. Islamic Management and Business, Vol.5 No11.

BPS. (2010). Penduduk Menurut Wilayah dan Agama yang Dianut. Retrieved April 30, 2016, from http://sp2010.bps.go.id/index.php/site/tabel?tid=321\&wid=0

Creswell, J. W. (2014). Pendekatan Kualitatif, Kuantitatif dan Mixed. Edisi Ketiga. Yogyakarta: Pustaka Pelajar.

Faisol, I. A. (2014). Pengaruh Penerapan E-Procurement Terhadap Pencegahan Fraud Di Sektor Publik. Jurnal Jaffa, Vol.02 No2.

Fajerial, E. (2014). KPK: Banyak Koruptor Muda, Ada Regenerasi Korupsi. Retrieved May 25, 2016, from http://m.tempo.co/read/news/2014/11/10/063620979/kpkbanyak-koruptor-muda-ada-regenerasi-korupsi

Hartanti, E. (2005). Tindak Pidana Korupsi. Jakarta: Sinar Grafika.

ICW. (2014). Tren Pemberantasan Korupsi Tahun 2014. Retrieved February 21, 2016, from http://www.antikorupsi.org/id/doc/tren-korupsi-2014

Kapardis, A., \& Kapardis, M. K. (2004). Enhancing Fraud Prevention and Detection by Profiling Fraud Offenders. Criminal Behaviour and Mental Health.

KPMG. (2011). Who Is The Typical Fraudster?. KPMG Analysis Of Global Patterns Of Fraud.

Margaretha. (2013). Mengapa Orang Melakukan Kejahatan? Retrieved March 30, 2016, from http://psikologi.unair.ac.id/artikel-mengapa-orang-melakukan-kejahatan/

Maulia, S. T. (2014). Pengaruh Usia, Pengalaman, Dan Pendidikan Dewan Komisaris Terhadap Kualitas Laporan Keuangan (Studi empiris pada perusahaan real estate dan property yang go public di Bursa Efek Indonesia tahun 2010-2012). Universitas Dipenogoro.

Rahmana, A. F. (2013). Analisis Pola Hubungan Kerugian Negara Akibat Korupsi Dengan Demografi Koruptor di Jawa Timur. Jurnal Sains Dan Seni Pomits, Vol 2 No 2.

Rastika, I. (2013). Orang-orang Pintar Terjerat Korupsi. Retrieved May 10, 2016, from http://nasional.kompas.com/read/2013/08/16/0919579/Orangorang.Pintar.Terjerat.Korupsi

Rzk. (2014). Ketua KPK: Korupsi Ternyata Meregenerasi. Retrieved May 26, 2015, from http://www.hukumonline.com/berita/baca/1t54879cbe2fccd/ketua-kpk--korupsiternyata-meregenerasi

Saefulloh, M. (2013). Tindak Pidana Korupsi Dalam Perspektif Hukum Islam dan UU No. 31 Tahun 1999 Tentang Pemberantasan Tindak Pidana Korupsi Jo Uu No. 20 Tahun 2001 Tentang Perubahan atas Uu No. 31 Tahun 1999. Universitas Mataram.

Shadabi, L. (2013). The Impact of Religion on Corruption. The Journal of Business Inquiry, Vol. 12, 102-117.

Singleton, T., \& Singleton, A. (2010). Fraud Auditing and Forensic Accounting. USA: Jhon Wiley \& Sons.

Sugiyono. (2009). Metode Penelitian Kuantitatif, Kualitatif dan $R \& D$. Bandung: Alfabeta.

Sumiarti. (2007). Pendidikan Anti Korupsi. Jurnal Pemikiran Alternatif Pendidikan, Vol12 No2.

Syamsuddin, A. (2011). Tindak Pidana Khusus. Jakarta: Sinar Grafika.

Wilopo. (2006). Analisis Faktor-faktor yang Berpengaruh Terhadap Kecenderungan Kecurangan Akuntansi: Studi pada Perusahaan Publik dan Badan Usaha Milik Negara di Indonesia. Simposium Nasional Akuntansi (SNA) 9 Padang.

Yanto, O. (2007). Pejabat, korupsi, dan penjara. Retrieved June 16, 2016, from http://www.antikorupsi.org/en/content/pejabat-korupsi-dan-penjara

Zaini, M. (2015). Analisis Pengaruh Fraud Diamond dan Gone Theory Terhadap Academic Fraud (Studi Kasus Mahasiswa Akuntansi Se-Madura). Simposium Nasional Akuntansi 18. 